\title{
Rekomendasi Fisioterapis Pada Pasien Low Back Pain Kronis
}

\author{
Kadek Yowanda Pangestu ${ }^{1 *}$, Dyah Pradnyaparamita Duarsa ${ }^{2}$, Ni Wayan Tianing ${ }^{3}$ \\ ${ }^{1}$ Program Studi Magister Ilmu Kesehatan Masyarakat, Universitas Udayana, Denpasar, Bali, ${ }^{2}$ Departemen \\ KMPK, Fakultas Kedokteran, Universitas Udayana, Denpasar, Bali ${ }^{3}$ Departemen Fisioterapi, Fakultas \\ Kedokteran, Universitas Udayana, Denpasar, Bali \\ *Email: kadekyowanda.p@gmail.com
}

\begin{abstract}
Background: Low Back Pain (LBP) chronic is a health problem that not only involves biomechanical factors but also involves cognitive, psychological, and social factors. The last decade has seen a shift in understanding in chronic case management that can affect physiotherapy recommendations for chronic LBP patients to return to work/activities normally. This study aims to determine the related between the characteristics of physiotherapists in Denpasar City and Badung Regency, attitudes and beliefs, as well as a diagnosis of the recommendations given in chronic LBP cases. Methods: The study design was a cross-sectional web-based survey with a total of 124 physiotherapists who are members of the Indonesian Physiotherapy Association (IFI), Central Bali Branch. Characteristics data were collected through a questionnaire, attitudes and beliefs with ABS-mp and PABS-PT, diagnosis and recommendations using a scenario. Data were analyzed using SPSS univariate, bivariate and multivariate. Results: Physiotherapists in Denpasar City and Badung Regency $21.8 \%$ have a biopsychosocial orientation. Multivariate analysis showed that the variable that had a significant relationship with physiotherapist recommendations was the personal interaction attitude variable with a value of $p=0.039($ AOR $=6.511$, 95\% CI = 1.099-38.581). Conclusion: Factors that related on recommendations physiotherapists to return to work/activities normally in patients with chronic LBP are age, work experience, training, personal interaction attitudes, physiotherapy beliefs, and physiotherapy diagnosis
\end{abstract}

Keywords: low back pain, physiotherapy, recommendations

\section{PENDAHULUAN}

Low Back Pain (LBP) merupakan masalah kesehatan yang umum terjadi di dalam suatu populasi dan menjadi penyebab utama kecacatan yang memengaruhi kinerja dan kesejahteraan dalam bekerja (Chou, 2010). Hasil estimasi beban global dari LBP yang dipelajari dari studi Global Burden of Disease (GBD) pada tahun 2010, LBP merupakan penyakit peringkat pertama yang menimbulkan disabilitas atau years lived with disability (YLD), dan menjadi peringkat keenam dalam disability adjusted life year (DALYs). Prevalensi global LBP adalah 9,4\% dimana DALY meningkat dari 58.2 juta (30\%) pada 1990 menjadi 83,0 juta (43\%) pada 2010.

Penelitian yang dilakukan oleh Kaur (2015), tentang prevalensi keluhan LBP pada petani di wilayah kerja UPT Kesmas Payangan Giayar pada bulan April 2015 menunjukkan bahwa sebanyak $68,6 \%$ responden mengeluh mengalami LBP dan angka kejadian LBP tertinggi ditemukan pada perempuan.

Faktor-faktor yang berkontribusi dalam tingginya angka kejadian LBP antara lain umur $>45$ tahun dengan lama kerja $>5$ jam, masa kerja $>10$ tahun, memiliki riwayat merokok, sering melakukan posisi bungkuk, tidak memiliki riwayat trauma, dan keluhan ditangani dengan pemijatan dengan tingkat disabilitas yang ringan (Kaur, 2015)

LBP dapat menyebabkan kecacatan yang berkepanjangan dan sangat berdampak kepada tingginya pembiyaan kesehatan dan berkurangnya pendapatan dikarenakan tidak dapat bekerja dan 
menurunkan produktivitas seseorang (Qaseem et al., 2017).

Sehingga orang dengan keluhan LBP kronis haruslah mendapatkan penanganan yang tepat dan efektif. Menurut American College of Physicians (ACP), penanganan LBP kronis terbagi menjadi 2 penanganan yaitu secara farmakologis dan non-farmakologis. Penanganan LBP kronis secara farmakologis pada tahap awal diberikan obat nonsteroidal anti-inflammatory dan pada tahap berikutnya dapat diberikan obat tramadol atau duloxetine. Sedangkan penanganan LBP kronis secara nonfarmakologis terdapat beberapa macam betuk pelayanan kesehatan salah satunya adalah Fisioterapi (Qaseem et al., 2017).

Permasalahan yang terjadi pada kasus LBP kronis tidak lagi dianggap sebagai murni permasalahan akibat struktural, kelainan anatomis atau masalah biomekanis pada tulang belakang tetapi juga terdapat interaksi faktor biopsikososial yang kompleks (Fersum et al., 2013). Sehingga permasalahan yang terjadi pada LBP kronis tidak hanya melibatkan faktor struktural atau biomekanik tetapi juga melibatkan faktor kognitif, psikologis, dan sosial. Adanya faktor kognitif, psikologis, dan sosial dianggap sebagai faktor-faktor yang dapat mempengaruhi prognosis pasien LBP kronis, sehingga konsekuensi yang harus di hadapi oleh fisioterapi adalah adanya perubahan penanganan yang semula menggunakan pendekatan biomedis mengarah kepada pendekatan biopsikososial (Fersum et al., 2013; Synnott et al., 2016).

Fisioterapis sebagai tenaga kesehatan yang berada di garis depan dalam penanganan LBP sangatlah penting untuk memiliki pemahaman yang jelas tentang sikap dan kepercayaan dalam penanganan LBP (Poitras et al., 2012). Memiliki pemahaman tentang sikap dan kepercayaan yang jelas, serta mengetahui hambatan yang akan dihadapi akan memungkinkan penerapan pedoman dan model pengobatan baru yang lebih efektif (Poitras et al., 2012).

Penelitian yang dilakukan oleh Derghazarian dan Simmonds (2011) yang menyatakan bahwa masih sedikit fisioterapis yang melakukan suatu penanganan LBP sesuai dengan pedoman yang berdasarkan pada praktek berbasis bukti yaitu sekitar 12\%. Hal ini menunjukkan adanya kurangnya kesadaran fisioterapis terhadap pedoman praktek yang dilandaskan pada praktek berbasis bukti. Kurangnya kesadaran tersebut merupakan hal yang sangat memprihatinkan, tetapi kekhawatiran terbesar adalah kenyataan bahwa diagnosis dan rekomendasi yang diberikan tidak sesuai dengan bukti terbaik.

Salah satu contoh ketidaksesuaian antara bukti terbaik dengan penanganan LBP adalah LBP seharusnya ditangani di layanan primary care terlebih dahulu, akan tetapi pada praktenya baik pada negara berpenghasilan tinggi, menengah maupun negara berpenghasilan rendah, orang-orang dengan LBP dirujuk pada layanan. Praktek berbasis bukti lainnya menyatakan bahwa pendekatan biopsikososial harusnya digunakan dalam melakukan penanganan LBP kronis dan pemberian latihan pada pasien merupakan rekomendasi terbaik, akan tetapi pada prakteknya assessment faktor psikososial pada pasien LBP kronis tidak secara rutin digunakan dan $54 \%$ orang dengan nyeri punggung bawah kronis di Amerika Serikat belum pernah diberikan exercise (Foster et al., 2018). 
Ketidaksesuaian antara bukti terbaik dengan penanganan LBP kronis yang berdampak pada pemberian rekomendasi yang tidak sesuai dengan evidence, akan menimbulkan kerugian dari sisi pasien. Beban pembiyaan kesehatan akan semakin tinggi namun dilain sisi juga tidak terjadi suatu perbaikan kondisi yang efektif (Foster et al., 2018).

Terdapat berbagai faktor yang berhubungan dengan ketidaksesuaian penanganan yang berdampak pada rekomendasi yang diberikan fisioterapis terutama terkait dengan merekomendasi pasien LBP kronis untuk tetap bekerja atau beraktivitas secara normal (Simmonds et al., 2012). Tujuan dalam penelitian ini adalah untuk mengetahui faktor-faktor yang berhubungan dengan rekomendasi yang diberikan fisioterapis pada kasus low back pain kronis.

\section{METODE PENELITIAN}

Jenis penelitian ini adalah survei berbasis web dengan desain crosssectional yang dilaksanakan pada organisasi Ikatan Fisioterapi Indonesia (IFI) cabang Bali Tengah dimana lingkup organisasi ini menaungi fisioterapis yang berada di wilayah Kota Denpasar dan Kabupaten Badung. Responden dalam penelitian adalah fisioterapis yang bekerja di rumah sakit negeri ataupun swasta dan bekerja di klinik fisioterapi mandiri, fisioterapis yang sudah pernah menagani kasus LBP dan bersedia dalam mengisi kuesioner dalam survei berbasis web. Responden dalam penelitian ini berjumlah 124 orang.

Penelitian ini telah mendapatkan Ethical Clearence dari Komisi Etik Fakultas Kedokteran Universitas Udayana Rumah Sakit Umum Pusat Sanglah Denpasar Bali No.
1103/UN14.2.2.VII.14/LT/2020 dan izin penelitian dari Dinas Penanaman Modal dan Perijinan Provinsi Bali serta Badan Kesatuan Bangsa dan Politik Kota Denpasar.

Kuisioner terdiri dari karekteristik responden, sikap interaksi personal, kepercayaan fisioterapis, diagnosis dan rekomendasi fisioterapis. Kuesioner sikap interaksi personal diadopsi dari kuesioner The Attitudes to Back Pain Scale for musculoskeletal practitioners (ABS-mp). Setiap item dinilai dengan menggunakan skala linkert yang terdiri dari enam poin yaitu; "1 = Sangat tidak setuju", "2 = Sebagian besar tidak setuju", "3=Tidak setuju ". "4 = Setuju dalam batasan tertentu", "5 = Sebagian besar setuju", "6 = Sangat Setuju" (Pincus et al., 2006).

Kuesioner kepercayaan fisioterapis menggunakan Pain Attitude and Beliefe Scale for Physiotherapists (PABS-PT). Instrumen PABS-PT terdiri dari 19 item pernyataan dimana 10 item pernyataan yang mengarah pada orientasi biomedis dan 9 item pernyataan yang mengarah pada orientasi biopsikososial. Setiap item dinilai dengan menggunakan skala linkert yang terdiri dari enam poin yaitu; "1 = Sangat tidak setuju", "2 = Sebagian besar tidak setuju", "3 = Tidak setuju ". "4 = Setuju dalam batasan tertentu", "5 = Sebagian besar setuju", "6 = Sangat Setuju". Skor pernyataan Skor yang lebih tinggi pada setiap sub-skala menunjukkan orientasi "Biomedis" atau "Biopsikososial" yang lebih kuat (Derghazarian and Simmonds, 2011).

Instrumen yang digunakan dalam mengukur diagnosis dan rekomendasi yang diberikan oleh fisioterapi melalui sebuah skenario kasus LBP kronis dimana skenario tersebut mendeskripsikan pasien dengan LBP kronis dengan resiko sedang 
dalam terjadinya disabilitas yang dikarenakan oleh faktor psikososial.

Berdasarkan skenario tersebut fisioterapis diminta untuk menilai tingkat keparahan spinal patologi dan menilai resiko terjadinya disabilitas terkait LBP dengan memberikan skor dari 0 sampai dengan 10. Fisioterapis juga ditanya seberapa setuju dengan pernyataan "Saya akan merekomendasikan pasien kembali bekerja/beraktivitas seperti biasa" dalam rentang nilai 0 sampai dengan 10 (Derghazarian and Simmonds, 2011).
Data Data dianalisis menggunakan SPSS secara univariat, bivariat dan multivariat.

\section{HASIL PENELITIAN}

Karakteristik responden (Tabel 1) menunjukkan bahwa usia minimum responden adalah 22 tahun dan usia maksimum responden adalah 61 tahun dengan mean (SD) 29,27 (6,77) dan median 27 tahun. Rentang usia responden penelitian sebagian besar berada pada rentang 26-35 tahun yaitu sebanyak $60,5 \%$ dan $26,6 \%$ responden penelitian berada pada rentang usia 17-25 tahun.

Tabel 1. Karakteristik Fisioterapis $(n=124)$

\begin{tabular}{|c|c|c|}
\hline Karakteristik & Frekuensi & $\begin{array}{l}\text { Proporsi } \\
\quad(\%)\end{array}$ \\
\hline \multicolumn{3}{|l|}{ Umur (tahun) } \\
\hline$<26$ & 33 & 26,6 \\
\hline $26-35$ & 75 & 60,5 \\
\hline $36-45$ & 11 & 8,9 \\
\hline $46-55$ & 4 & 3,2 \\
\hline $56-65$ & 1 & 0,8 \\
\hline \multicolumn{3}{|l|}{ Pendidikan Terakhir } \\
\hline D3 & 23 & 18,5 \\
\hline S-1/D-IV & 27 & 21,8 \\
\hline Profesi & 59 & 47,6 \\
\hline S-2 & 15 & 12,1 \\
\hline \multicolumn{3}{|l|}{ Lama Kerja (tahun) } \\
\hline$\leq 10$ & 106 & 85,5 \\
\hline$>10$ & 18 & 14,5 \\
\hline \multicolumn{3}{|l|}{ Pelatihan } \\
\hline $\begin{array}{l}\text { Tidak pernah mengikuti pelatihan } \\
\text { biospikososial }\end{array}$ & 109 & 87,9 \\
\hline Pernah mengikuti pelatihan biopsikososial & 15 & 12,1 \\
\hline \multicolumn{3}{|l|}{$\begin{array}{l}\text { Jumlah Pasien LBP Kronis yang ditangani } \\
\text { dalam } 1 \text { bulan terakhir }\end{array}$} \\
\hline$<5$ Pasien & 18 & 14,5 \\
\hline 5-10 Pasien & 47 & 37,9 \\
\hline 11-15 Pasien & 13 & 10,5 \\
\hline$>15$ Pasien & 46 & 37,1 \\
\hline $\begin{array}{lllr}\text { Fisioterapis } & \text { di Kota } & \text { Denpasar } & \text { dan } \\
\text { Kabupaten } & \text { Badung } & \text { sebagian } & \text { besar }\end{array}$ & $\begin{array}{ll}\text { ir } & \text { adalah } \\
\text { \%) } & \text { dan }\end{array}$ & $\begin{array}{l}\text { pendidikan } \\
\text { pendidikan }\end{array}$ \\
\hline
\end{tabular}


sebagian besar $(85,5 \%)$ fisioterapis di Kota Denpasar dan Kabupaten Badung memiliki lama bekerja $\leq 10$ tahun dan sebanyak $14,5 \%$ memiliki pengalaman kerja >10 tahun. Jumlah pasien LBP kronis yang ditangani dalam satu bulan terakhir sebagian besar berada pada rentang 5-10 pasien $(37,9 \%)$ dan $>15$ pasien $(37,1 \%)$.

Sikap interaksi personal dan kepercayaan fisioterapis menunjukkan bahwa gambaran sikap interaksi personal fisioterapis di di Kota Denpasar dan Kabupaten Badung terhadap kasus LBP kronis sebagian besar menunjukkan sikap yang cukup yaitu sebanyak $46,8 \%$ dan sikap interpersonal baik sebanyak $21 \%$. Pada tabel 2 menunjukkan gambaran kepercayaan fisioterapis sebagian besar memiliki kepercayaan biomedis $(78,2 \%)$ dibandingkan dengan fisioterapis yang memiliki kepercayaan biopsikososial $(21,8 \%)$.

Tabel 2. Gambaran Sikap Interaksi personal dan Kepercayaan Fisioterapis ( $n=124)$

\begin{tabular}{lccc}
\hline \multicolumn{1}{c}{ Variabel } & Frekuensi & Proporsi (\%) & Median (IQR) \\
\hline Sikap Interaksi & & & $75(7)$ \\
Personal & & & \\
$\quad$ Kurang & 40 & 32,3 & \\
Cukup & 58 & 46,8 & \\
$\quad$ Baik & 26 & 21 & \\
Kepercayaan & & & \\
Fisioterapis & & & $46(6)$ \\
$\quad$ Biomedis & 97 & 78,2 & $37(8)$ \\
$\quad$ Biopsikososial & 27 & 21,8 & \\
\hline
\end{tabular}

Tabel 3. Distribusi Rekomendasi Fisioterapis Berdasarkan Karakteristik Fisioterapis di Kota Denpasar dan Kabupaten Badung ( $\mathrm{n}=124)$

\begin{tabular}{|c|c|c|c|}
\hline \multirow{2}{*}{ Variabel } & \multicolumn{2}{|c|}{$\begin{array}{c}\text { Rekomendasi Fisioterapis Kembali } \\
\text { Bekerja }\end{array}$} & \multirow{2}{*}{ Nilai p } \\
\hline & $\begin{array}{c}\text { Sangat Tidak } \\
\text { Setuju }\end{array}$ & Sangat Setuju & \\
\hline \multicolumn{4}{|c|}{ Umur (tahun)** } \\
\hline$<26$ & $15(45,5)$ & $18(54,5)$ & \multirow{5}{*}{$0,02 *$} \\
\hline $26-35$ & $36(48,0)$ & $39(43,5)$ & \\
\hline $36-45$ & $1(9,1)$ & $10(90,9)$ & \\
\hline $46-55$ & $0(0,0)$ & $4(100)$ & \\
\hline $56-65$ & $0(0,0)$ & $1(100)$ & \\
\hline \multicolumn{4}{|c|}{ Pendidikan Terakhir } \\
\hline D3 & $9(39,1)$ & $14(60,9)$ & \multirow{4}{*}{0,81} \\
\hline S-1/D-IV & $11(40,7)$ & $16(59,3)$ & \\
\hline Profesi & $24(40,7)$ & $35(59,3)$ & \\
\hline$S-2$ & $8(53,3)$ & $7(46,7)$ & \\
\hline \multicolumn{4}{|c|}{ Lama Kerja (tahun)** } \\
\hline$\leq 10$ & $49(46,2)$ & $57(53.8)$ & 0,019 \\
\hline
\end{tabular}




\begin{tabular}{lccc}
\hline$>10$ & $3(16,7)$ & $15(83.3)$ & \\
$\begin{array}{l}\text { Pelatihan** } \\
\text { Tidak pernah mengikuti } \\
\text { pelatihan biospikososial }\end{array}$ & $51(46,8)$ & $58(53,2)$ & \\
$\begin{array}{l}\text { Pernah mengikuti pelatihan } \\
\text { biopsikososial }\end{array}$ & $1(6,7)$ & $14(93,3)$ & 0,03 \\
\hline $\begin{array}{l}* \text { Expected count }<5 \text { ditemukan pada lebih dai 20\% sel (Fisher exact) } \\
* * p<0,05, \text { signifikan berhubungan }\end{array}$ &
\end{tabular}

Berdasarkan pada Tabel 3 memiliki hubungan dengan rekomendasi menyajikan hasil tabulasi silang (chi- fisioterapi adalah faktor yang memiliki square) antara umur, pendidikan terahir, nilai $\mathrm{p}<0,05$ yaitu variabel umur, lama lama kerja dan pelatihan dengan kerja, dan pelatihan yang pernah diikuti. rekomendasi fisioterapi. Faktor yang

Tabel 4. Distribusi Rekomendasi Fisioterapis Berdasarkan Sikap Interaksi Personal, Kepercayaan Fisioterapis dan Diagnosis di Kota Denpasar dan Kabupaten Badung $(\mathrm{n}=124)$

\begin{tabular}{lccc}
\hline & \multicolumn{2}{c}{$\begin{array}{c}\text { Rekomendasi Fisioterapis } \\
\text { Kembali Bekerja }\end{array}$} & \multirow{2}{*}{ Nilai p } \\
\cline { 2 - 3 } Variabel & $\begin{array}{c}\text { Sangat Tidak } \\
\text { Setuju }\end{array}$ & Sangat Setuju & \\
\hline Sikap Interaksi & & & \\
Personal** & & & \\
Kurang & $23(57,5)$ & $17(42,5)$ & \multirow{2}{*}{0,001} \\
Cukup & $26(44,8)$ & $32(52,2)$ & \\
Baik & $3(11,5)$ & $23(88,5)$ & \\
Kepercayaan & & & \\
Fisioterapis** & & & \\
Biomedis & $52(40,7)$ & $45(56,3)$ & \\
Biopsikososial & $0(0,0)$ & $27(100)$ & \\
Diagnosis** & & & \\
Gangguan Spinal* & & & \\
Sangat Ringan & $0(0,0)$ & $2(100)$ & \\
Ringan & $4(16,7)$ & $20(83,3)$ & \\
Moderate & $27(47,4)$ & $30(52,6)$ & \\
Parah & $18(50,0)$ & $18(50,0)$ & \\
Sangat Parah & $3(60,0)$ & $2(40,0)$ & \\
Disabilitas* & & & \\
Sangat Rendah & $3(33,3)$ & $6(66,7)$ & \\
Rendah & $6(17,6)$ & $28(82,4)$ & \\
Moderate & $23(51,1)$ & $22(48,9)$ & \\
Tinggi & $19(55,9)$ & $15(44,1)$ & \\
Sangat Tinggi & $1(50,0)$ & $1(50,0)$ & \\
\hline
\end{tabular}


* Expected count $<5$ ditemukan pada lebih dai $20 \%$ sel (Fisher exact)

$* * \mathrm{p}<0,05$, signifikan berhubungan

Berdasarkan tabel 4 menyajikan hasil tabulasi silang antara sikap interaksi personal, kepercayaan fisioterapis, dan diagnosis dengan rekomendasi fisioterapi. Faktor yang memiliki hubungan dengan rekomendasi fisioterapi adalah faktor yang memiliki nilai $\mathrm{p}<0,05$ yaitu variabel diagnosis dan sikap interaksi personal, dan nilai p <0,0001 yaitu kepercayaan fisioterapis.

Tabel 5. Hasil Analisis Multivariat

\begin{tabular}{|c|c|c|c|c|}
\hline Variabel & AOR & $95 \% \mathrm{CI}$ & Nilai $p$ & $\mathbf{R}^{2}$ \\
\hline Umur (tahun) & & & & 0,541 \\
\hline$<26$ & 1 (Ref) & & & \\
\hline $26-35$ & 0,563 & $0,180-1,764$ & 0,324 & \\
\hline $36-45$ & 30,944 & $0,801-1195,8$ & 0,066 & \\
\hline $46-55$ & 0,035 & $0,000-0,000$ & 1,000 & \\
\hline $56-65$ & 0,000 & $0,000-0,000$ & 1,000 & \\
\hline \multicolumn{5}{|l|}{ Pendidikan Terakhir } \\
\hline D3 & 1 (Ref) & & & \\
\hline S-1/D-IV & 1,192 & $0,293-4,853$ & 0,806 & \\
\hline Profesi & 0,323 & $0,088-1,192$ & 0,090 & \\
\hline$S-2$ & 0,106 & $0,011-1,071$ & 0,998 & \\
\hline \multicolumn{5}{|l|}{ Lama Kerja } \\
\hline$\leq 10$ & $1(\operatorname{Ref})$ & & & \\
\hline$>10$ & 0,482 & $0,034-6,822$ & 0,589 & \\
\hline \multicolumn{5}{|l|}{ Pelatihan } \\
\hline $\begin{array}{l}\text { Tidak pernah mengikuti } \\
\text { pelatihan biospikososial }\end{array}$ & 1 (Ref) & & & \\
\hline $\begin{array}{l}\text { Pernah mengikuti pelatihan } \\
\text { biopsikososial }\end{array}$ & 0,000 & $0,000-0,000$ & 0,998 & \\
\hline \multicolumn{5}{|l|}{ Sikap Interaksi Personal } \\
\hline Kurang & 1 (Ref) & & & \\
\hline Cukup & 1,032 & $0,356-2,995$ & 0,166 & \\
\hline Baik & 6,511 & $1,099-38,581$ & $0,039 * *$ & \\
\hline \multicolumn{5}{|l|}{ Kepercayaan Fisioterapis } \\
\hline Biomedis & 1 (Ref) & & & \\
\hline Biopsikososial & 8,630 & $0,000-0,000$ & 0,997 & \\
\hline \multicolumn{5}{|l|}{ Diagnosis } \\
\hline \multicolumn{5}{|l|}{ Gangguan Spinal } \\
\hline Sangat Ringan & 1 (Ref) & & & \\
\hline Ringan & 0,000 & $0,000-0,000$ & 0.999 & \\
\hline Moderate & 0,000 & $0,000-0,000$ & 0.999 & \\
\hline Parah & 0,000 & $0,000-0,000$ & 0.999 & \\
\hline Sangat Parah & 0,000 & $0,000-0,000$ & 0.999 & \\
\hline
\end{tabular}




\begin{tabular}{lccc}
\hline Disabilitas & & & \\
Sangat Rendah & $1($ Ref $)$ & & \\
Rendah & 13,361 & $0,841-212,282$ & 0.066 \\
Moderate & 5,350 & $0,360-79,471$ & 0,223 \\
Tinggi & 7,770 & $0,519-116,400$ & 0,138 \\
Sangat Tinggi & 1,155 & $0,007-181,099$ & 0,955 \\
\hline$* * \mathrm{p}<0,05$ & & &
\end{tabular}

Berdasarkan hasil analisis multivariat hubungan umur, pendidikan terakhir, lama kerja, pelatihan, sikap interaksi personal, kepercayaan fisioterapis dan diagnosis dengan rekomendasi fisioterapis di Kabupaten Badung dan Kota Denpasar seperti yang ditampilkan pada Tabel 5.

Faktor yang memiliki hubungan yang signifikan dengan rekomendasi fisioterapis adalah variabel sikap interaksi personal dengan nilai $\mathrm{p}=0,039$ (AOR $=6,511,95 \% \mathrm{CI}=1,099-38,581)$ dan nilai $\mathrm{R}^{2}=0,541$ menunjukkan bahwa kemampuan faktor umur, pendidikan terakhir, lama kerja, pelatihan, sikap interaksi personal, kepercayaan fisioterapis dan diagnosis yang diteliti pada penelitian ini dalam menjelaskan varians dari rekomendasi fisioterapis adalah sebesar 54,1\%. Sebesar 45,9\% varians rekomendasi dijelaskan oleh faktor lain yang tidak diteliti pada penelitian ini.

\section{PEMBAHASAN}

Hasil dari penelitian ini adalah terdapat hubungan yang signifikan antara umur dan lama kerja dengan rekomendasi fisioterapi terkait dengan kembali bekerja/beraktivitas normal pada pasien LBP kronis. Hal ini sesuai dengan penelitian Simmonds et al. (2012) yang menyatakan bahwa umur dan lama kerja seorang fisioterapis mempengaruhi ketakutan dalam menangani kasus nyeri.
Fisioterapis yang lebih tua dan memiliki lebih banyak pengalaman klinis akan memiliki ketakutan yang rendah dalam menangani kasus nyeri dan lebih percaya dengan kemampuan yang mereka miliki dan mempengaruhi rekomendasi yang diberikan kepada pasien.

Fisioterapis dengan pengalaman kerja yang lebih panjang, mengadopsi pendekatan pengambilan keputusan yang lebih spesifik, kreatif dan disempurnakan terhadap kebutuhan individu pasien dan dimensi kontekstual yang unik (Smith et al., 2008). Fisioterapis menggunakan lebih banyak interpretasi dan kritik dalam pengambilan keputusan, menjadi semakin percaya diri dan percaya diri (Smith et al., 2008). Umur dan lama kerja seorang fisioterapis akan berdampak kepada kepribadian dari fisioterapis itu sediri yang mempengaruhi dalam pengambilan keputusan termasuk pemberian rekomendasi pada pasien LBP kronis (Holdar et al., 2013). Fisioterapis muda yang belum memiliki pengalaman klinis yang panjang cenderung menggunakan pendekatan biomedis dalam melakukan penanganan LBP dibandingkan dengan fisioterapis senior dengan pengalaman klinis yang panjang, sedangkan latar belakang pendidikan fisioterapi tidak memiliki peran yang berati dalam memberikan rekomendasi kepada pasien (Alshehri et al., 2020).

Fisioterapis yang pernah mengikuti pelatihan biopsikososial akan merekomendasikan pasien LBP kronis 
untuk bekerja/beraktivitas kembali secara normal dibandingkan dengan fisioterapis yang belum pernah mengikuti pelatihan biopsikososial. Hasil ini sejalan dengan penelitian yang dilakukan oleh Domenech et al. (2011) dalam penelitiannya tentang dampak sesi pelatihan biomedis dan biopsikososial pada sikap, kepercayaan, dan rekomendasi penyedia layanan kesehatan terhadap LBP kronis mendapatkan hasil bahwa partisipan yang mengkuti sesi pelatihan biopsikososial memiliki hubungan yang kuat dalam meningkatkan aktivitas klinik dan rekomendasi yang diberikan kepada pasien LBP kronis.

Pelatihan dengan pendekatan biopsikososial adalah intervensi baru dalam 1 dekade terakhir sehingga dalam penelitian ini fisioterapis dengan pengalaman kerja $>10$ tahun $88,9 \%$ belum pernah mengikuti pelatihan yang berkaitan dengan pendekatan biopsikososial. Fisioterapis yang pernah mengikuti pelatihan biopsikososial dalam menangani kasus LBP kronis, akan mengalami perubahan sudut pandang dalam penanganan LBP kronis.

Secara garis besar perubahan yang terjadi dari fisioterapis adalah menganggap bahwa pendekatan biopsikososial merupakan hal baru dan menjadi tantangan dalam belajar, fisioterapis merasa bahwa pendekatan biopsikososial mencerminkan kompleksitas multidimensi dari LBP kronis ataupun LBP kronis non-spesifik. Tantangan yang fisioterapis hadapi adalah mempertimbangkan faktor-faktor lain yang menyebabkan nyeri tersebut dan hal ini mengharuskan fisioterapis memperluas ruang lingkup penanganan dalam praktek di luar faktor fisik (Cowell et al., 2018).
Mengidentifikasi faktor-faktor lain penyebab dari LBP kronis sangatlah penting untuk dilakukan oleh seorang fisioterapis sehingga tercapainya penanganan pada pasien yan lebih efektif (Sterling et al., 2019). Hasil dari penelitian ini adalah adanya hubungan yang sinifikan antara sikap interaksi personal fisioterapis dengan rekomendasi kembali bekerja/braktivitas secara normal pada pasien LBP. Hasil ini sejalan dengan penelitian Gardner et al., (2017) yang mengatakan bahwa diperlukan adanya suatu hubungan sikap yang baik antara fisioterapis dan pasien dengan LBP kronis. Mengidentifikasi faktor-faktor lain penyebab nyeri diperlukan sebuah interaksi personal yang baik antara fisioterapis dan pasien.

Pasien dengan LBP kronis mengharapkan kejelasan diagnosis, pengurangan rasa sakit dan terapi manual sebagai bagian dari penanganan, dimana hal tersbut merupakan cerminan keyakinan secara biomedis pasien mengenai LBP kronis yang diderita (Gardner et al., 2017). Harapan yang diinginkan pasien tentu saja terdapat beberapa yang tidak sesuai dengan pedoman klinis sehingga diperlukan adanya sikap interaksi personal yang baik antara fisioterapis dengan pasien sehingga terjadi suatu pemahaman yang sama mengenai LBP kronis yang diderita (Gardner et al., 2017).

Selain sikap, kepercayaan seorang fisioterapis juga memainkan peran yang sangat penting dalam fisioterapis memberikan suatu rekomendasi pasien LBP kronis untuk kembali bekerja atau beraktivitas secara normal. Hasil dari penelitian ini adalah terdapat hubungan yang signifikan antara kepercayaan fisioterapi terhadap rekomendasi yang 
diberikan. Hal ini sejalan dengan penelitian Derghazarian and Simmonds (2011) yang mengatakan bahwa fisioterapis dengan kepercayaan biomedis menunjukkan hasil diagnosis derajat keparahan dari adanya spinal patologi lebih tinggi dan hal ini juga sangat berpengaruh terhadap rekomendasi yang diberikan yaitu tidak menyetujui rekomendasi untuk pasien kembali beraktivitas seperti biasanya.

Fisioterapis yang memiliki kepercayaan biomedis akan menerjemahkan nyeri sebagai nyeri adalah akibat langsung dari kerusakan atau cedera jaringan, bahwa perjalanan nyeri berasal dari sumber nyeri kemudian dilanjutkan ke otak dan bahwa rasa sakit yang dialami seseorang berbanding lurus dengan kerusakan atau cidera jaringan yang dialami (Keefe, 2011). Penanganan LBP dengan menggunakan pendekatan biomedis lebih berfokus pada organ atau jaringan yang menjadi sumber permasalahan LBP tersebut (Simmonds et al., 2012).

Sehingga dalam melakukan diagnosis terhadap patologi yang terjadi pada tulang belakang dan resiko terjadinya disabilitas dinilai tinggi, meskipun bahwa patologi dan disabilitas merupakan konstruksi yang berbeda akan tetapi hal ini mengindikasikan bahwa fisioterapis memberikan selektif penting untuk kesimpulan patologi dijadikan dasar dalam memprediksi resiko pasien mengalami kecacatan dan berdampak pada tidak merekomendasikan pasien LBP kronis untuk kembali bekerja atau beraktivitas secara normal (Simmonds et al., 2012).

\section{KESIMPULAN DAN SARAN}

Dari hasil penelitian ini dapat disimpulkan bahwa faktor-faktor yang memiliki hubungan dengan pemberian rekomendasi fisioterapi terkait dengan rekomendasi untuk kembali bekerja/beraktivias secara normal pada pasien LBP kronis adalah umur, lama kerja, pelatihan, sikap interaksi personal, kepercayaan fisioterapi, dan diagnosis fisioterapi.

Bagi penelitian selanjutnya, dapat dilakukan penelitian lebih dalam lagi tentang studi rekomendasi ini dengan menggali faktor-faktor lain yang memiliki hubungan dengan pemberian rekomendasi pada pasien LBP kronis ini. Penggunaan metode penelitian mix method juga disarankan dalam penelitian selanjutnya, dimana selain mengambil data secara kuantitatif dari fisioterapi juga dapat menggali lebih dalam bagaimana seorang fisioterapis menilai suatu kasus LBP kronis berdasarkan skenario yang ada sehingga menghasilkan suatu kesimpulan setuju atau tidak untuk merekomendasikan pasien LBP kronis untuk bekerja/beraktivitas secara normal.

\section{DAFTAR RUJUKAN}

Alshehri, M. A., Alzahrani, H., Alotaibi, M., Alhowimel, A. And Khoja, O. (2020). Physiotherapists' Pain Attitudes and Beliefs Towards Chronic Low Back Pain and Their Association with Treatment Selection: A Cross-Sectional Study, BMJ Open, 10(6), P. 1-12. DOI: 10.1136/Bmjopen-2020-037159.

Chou, R. (2010). Pharmacological Management of Low Back Pain, Neurologist, $\quad 70(4) . \quad$ DOI: 10.5694/J.1326- 
5377.1954.Tb66886.X.

Cowell, I., O’Sullivan, P., O'Sullivan, K., Poyton, R., Mcgregor, A. And Murtagh, G. (2018). The Perspectives of Physiotherapists on Managing Nonspecific Low Back Pain Following A Training Programme In Cognitive Functional Therapy: A Qualitative Study, Musculoskeletal Care, 17(1), P. 7990. DOI: 10.1002/Msc.1370.

Derghazarian, T. And Simmonds, M. J. (2011). Management Of Low Back Pain By Physical Therapists In Quebec: How Are We Doing?, Physiotherapy Canada, 63(4), P. 464-473. DOI: 10.3138/Ptc.2010$04 \mathrm{P}$.

Domenech, J., Sánchez-Zuriaga, D., Segura-Ortí, E., Espejo-Tort, B. And Lisón, J. F. (2011). Impact of Biomedical and Biopsychosocial Training Sessions on The Attitudes, Beliefs, And Recommendations of Health Care Providers About Low Back Pain: A Randomised Clinical Trial, Pain. International Association For The Study Of Pain, 152(11), P. 2557-2563. DOI: 10.1016/J.Pain.2011.07.023.

Fersum, K. V., O’Sullivan, P., Skouen, J. S., Smith, A. And Kvåle, A. (2013). Efficacy of Classification-Based Cognitive Functional Therapy in Patients with Non-Specific Chronic Low Back Pain: A Randomized Controlled Trial, European Journal Of Pain (United Kingdom), 17(6), P. 916-928. DOI: 10.1002/J.15322149.2012.00252.X.
Foster, N. E., Anema, J. R., Cherkin, D., Chou, R., Cohen, S. P., Gross, D. P., Et Al. (2018). Prevention and Treatment of Low Back Pain: Evidence, Challenges, And Promising Directions, The Lancet, 391(10137), P. 2368-2383. DOI: 10.1016/S0140-6736(18)30489-6.

Gardner, T., Refshauge, K., Smith, L., Mcauley, J., Hübscher, M. And Goodall, S. (2017). Physiotherapists' Beliefs and Attitudes Influence Clinical Practice in Chronic Low Back Pain: A Systematic Review Of Quantitative And Qualitative Studies, Journal of Physiotherapy. Korea Institute Of Oriental Medicine, 63(3), P. 132143. DOI: 10.1016/J.Jphys.2017.05.017.

Holdar, U., Wallin, L. And Heiwe, S. (2013). Why Do We Do As We Do? Factors Influencing Clinical Reasoning and Decision-Making Among Physiotherapists in An Acute Setting, Physiotherapy Research International, 18(4), P. 220-229. DOI: 10.1002/Pri.1551.

Kaur, K. (2015). Prevalensi Keluhan Low Back Pain (Lbp) pada Petani di Wilayah Kerja Upt Kesmas Payangan Gianyar April 2015, 5(1), P. 49-59.

Keefe, F. J. 2011. Behavioral Medicine: $A$ Voyage to The Future, Annals of Behavioral Medicine, 41(2), P. 141151. DOI: $10.1007 / \mathrm{S} 12160-010-$ 9239-8. 
Pincus, T., Vogel, S., Santos, R., Breen, A., Foster, N. And Underwood, M. (2006). The Attitudes to Back Pain Scale In Musculoskeletal Practitioners (ABS-Mp), The Clinical Journal Of Pain, 22(4), P. 378-386.

DOI: 10.1097/01.Ajp.0000178223.85636. 49.

Poitras, S., Durand, M. J., Côté, A. M. And Tousignant, M. (2012). Guidelines on Low Back Pain Disability: Interprofessional Comparison of Use Between General Practitioners, Occupational Therapists, and Physiotherapists., Spine, 37(14), P. 1252-1259. DOI: 10.1097/BRS.0b013e31824b6adf.

Qaseem, A., Wilt, T. J., Mclean, R. M. And Forciea, M. A. (2017). Noninvasive Treatments For Acute, Subacute, And Chronic Low Back Pain: A Clinical Practice Guideline From The American College of Physicians, Annals of Internal Medicine, 166(7), p. 514-530. DOI: 10.7326/M16-2367.

Simmonds, M. J., Derghazarian, T. and Vlaeyen, J. W. S. (2012). Physiotherapists' Knowledge, Attitudes, and Intolerance of Uncertainty Influence Decision Making in Low Back Pain. 2012;28(6):467-74., The Spine Journal, 12(10), p. 974. DOI: 10.1016/j.spinee.2012.09.020.

Smith, M., Higgs, J. and Ellis, E. (2008). Factors Influencing Clinical Decision Making, Clinical Reasoning and Clinical Decision
Making, 74(6), p. 675-676. DOI: 10.4103/0378-6323.45131.

Sterling, M., de Zoete, R. M. J., Coppieters, I. and Farrell, S. F. (2019). Best Evidence Rehabilitation for Chronic Pain Part 4: Neck Pain, Journal of Clinical Medicine, 8(8), p. 1219. DOI: $10.3390 / \mathrm{jcm} 8081219$.

Synnott, A., O'Keeffe, M., Bunzli, S., Dankaerts, W., O'Sullivan, P., Robinson, K., et al. (2016). Physiotherapists Report Improved Understanding of and Attitude Toward the Cognitive, Psychological and Social Dimensions of Chronic Low Back Pain After Cognitive Functional Therapy Training: A Qualitative Study, Journal of Physiotherapy. Korea Institute of Oriental Medicine, 62(4), p. 215-221. DOI: 10.1016/j.jphys.2016.08.002. 